УДК 342.95 (477)

DOI https://doi.org/10.32844/2618-1258.2019.3-1.32

HECTOP H.B.

\title{
НОРМОТВОРЧІСТЬ, ЕКСПЕРТИЗА, МОНІТОРИНГ ЯК АДМІНІСТРАТИВНІ ФОРМИ КОНТРОЛЮ ТА ПРОЦЕДУРИ ЇХ ЗДІЙСНЕННЯ
}

У статті автор доводить, що форми (процедури) контролю зокрема та управлінської діяльності взагалі є досить дискусійними поняттями. Адже їхній зміст може бути наповнено авторським тлумаченням і сприйняттям, що буде суттєво відрізнятися у різних науковців, і щодо неоднакових предметів регулювання. Окреслено загальні теоретичні аспекти нормотворчості, експертизи та моніторингу (спостереження, аналізу) як адміністративних форм контролю. Визначено, що експертиза як форма контролю за судом і суддями - це виконання правової оцінки, юридичної експертизи національного законодавства, яке стосується сфери судоустрою та правосуддя, за результатами якої приймається юридично значиме рішення, що має обов'язковий чи факультативний характер, може зумовити втрату чинності правових норм чи зобов'язання держави відкоригувати їхній зміст. Доведено, що спостереження як форма контролю - систематична моніторингово-аналітична функція визначеного або невизначеного законом кола осіб щодо суду та суддів, що полягає в накопиченні, оприлюдненні, передачі третім особам зібраних даних, які стосуються оптимальності структурних зв'язків у судовій системі, систематичне спостереження за дотримання закону суддями, вивчення дисциплінарної практики Вищої ради правосуддя тощо з обмеженою можливістю настання прямих юридичних наслідків для об'єктів контролю. Виокремлено такі види адміністративних процедур, що відповідають моніторингу (спостереженню, аналізу) як формі контролю: 1) спостереження за дотриманням закону суддями у професійній діяльності; 2) спостереження за дотриманням суддями та кандидатами на посаду судді кваліфікаційних та особистісних вимог до особи судді; 3) моніторинг оптимальності структури судоустрою, правового статусу судів, суддів, органів суддівського врядування та самоврядування; 4) моніторинг додержання вимог законодавства щодо врегулювання конфлікту інтересів; організаційно-фінансове забезпечення роботи суду; 5) аналітика дисциплінарної та кваліфікаційної практики органів суддівського врядування. Зроблено висновок, що форми контролю - нормотворчість; експертиза; моніторинг (спостереження, аналіз) та адміністративні процедури, що здійснюються в їхніх межах, у найбільш повному та оптимальному форматі характеризують формалізацію управлінського впливу на судову сферу.

Ключові слова: контроль, суддя, нормотворчість, експертиза, моніторинг, спостереження, адміністративні форми, адміністративні проиедури.

In the article the author proves that the forms (procedures) of control in particular and of management activity in general are quite debatable concepts. After all, their content can be filled with author's interpretations and perceptions, which will differ substantially from different scholars, and about different subjects of regulation. The general theoretical aspects of rulemaking, expertise and monitoring (observation, analysis) as administrative forms of control are outlined. It is determined that examination as a form of control over the court and judges is the performance of a legal assessment, legal expertise of national law relating to the field of justice and justice, the results of which make a legally significant decision, which is binding or optional, may lead to the loss of validity legal norms or the obligation of the state to correct their content. It is proved that surveillance as a form of control is a systematic monitoring and analytical function of a defined

(C) НЕСТОР Н.В. - кандидат юридичних наук, здобувач (Відкритий міжнародний університет розвитку людини «Україна») 
or undefined circle of persons concerning the court and judges, which consists in the accumulation, disclosure, transfer to the third parties of the collected data concerning the optimality of the structural links in the judicial system, systematic for the observance of the law by the judges, the study of disciplinary practice of the High Council of Justice, etc. with limited possibility of direct legal consequences for the objects of control. The following types of administrative procedures corresponding to monitoring (observation, analysis) as a form of control are distinguished: 1) observing the observance of the law by judges in their professional activities; 2) observing the judges and candidates adherence to the qualification and personal requirements for the judge's personality; 3) monitoring the optimality of the structure of the judiciary, the legal status of courts, judges, judicial and self-government bodies; 4) monitoring compliance with the requirements of the legislation on conflict of interest management; organizational and financial support of the court; 5) analytics of disciplinary and qualification practice of judicial administration bodies. The conclusion is that forms of control are rulemaking; expertise; monitoring (observation, analysis), and the administrative procedures carried out within them, in the most complete and optimal format, characterize the formalization of managerial influence on the judicial sphere.

Key words: control, judge, rulemaking, examination, monitoring, observation, administrative forms, administrative procedures.

Вступ. Форми (процедури) контролю зокрема та управлінської діяльності взагалі є досить дискусійними поняттями. Хоча, аналізуючи праці різних учених із цього приводу, доходимо до висновку, що в цьому випадку мова йде не стільки про дискусію чи полеміку, скільки про багатовекторність сприйняття цих категорій. Тобто науковці пропонують різні моделі їх використання у власних дослідженнях, відповідно видозмінюючи їхню юридичну природу та змістовне, понятійне наповнення.

Традиційно в сучасній юридичній науці нормотворчість розглядається як процес пізнання і оцінювання правових потреб суспільства і держави, формування і прийняття нормативно-правових актів уповноваженими суб'єктами в межах відповідних процедур. До цього їх спонукають суспільна проблема, невирішене питання, яке має значення для багатьох людей і для держави загалом $[1$, с. 146]. Очевидно, що правове регулювання судової сфери має велике значення для суспільства; так само очевидним $€$ його вплив на функціонування судової системи країни.

Виділення такої форми контролю, як експертиза, пов'язано з можливістю третіх осіб, не наділених законодавчими повноваженнями, приймати юридично значимі рішення, під час яких здійснюються професійна оцінка, юридична експертиза положень законодавства. Авторитет висновків експертів, як зазначає В.Г. Гончаренко, надзвичайно високий, оскільки в них зосереджена передова наукова думка і багаторазово перевірений досвід професіоналів [2, с. 2]. Експертне дослідження є системою логічних та інших інструментальних операцій (способів, прийомів) отримання даних для вирішення питання, що поставлено перед експертом (експертною установою) [3, с. 108]. Традиційно експертиза асоціюється 3 процесом доказування для цілей судочинства. Наприклад, згідно з статтями 68, 69 Кодексу адміністративного судочинства, експертом може бути особа, яка володіє спеціальними знаннями, необхідними для з'ясування відповідних обставин справи. Як експерт із питань права може залучатися особа, яка має науковий ступінь та $\epsilon$ визнаним фахівцем у галузі права [4]. Водночас подібна сфера використання не $є$ вичерпною, допускає можливості експертних висновків, досліджень і в інших галузях застосування. Так само широко може трактуватися і коло експертних установ.

Найбільш усіченим із погляду обсягу, сили управлінського впливу є спостереження (моніторинг, аналіз), адже фактично передбачає отримання, фіксування, оприлюднення певних знань чи інформації. Безпосередній вплив на правовий статус суду чи суд $є$ обмеженим. Тому загалом погоджуємося з В.Б. Авер'яновим, яких трактує моніторинг як пасивну форму контролю, пов'язану з відстеженням певної ситуації чи процесу у сфері управління [5, с. 433]; постійне, безперервне спостереження за відповідністю об'єкта контролю стандартам, нормам і правилам, визначеним законодавством, станом реалізації управлінських рішень із метою оцінки поточного i прогнозного (можливого) стану підконтрольного суб'єкта [6, с. 54]. По суті, це є допоміжна форма контролю, здійснення процедур якої зумовлює початок процедур у межах інших форм контролю. 
Аналіз останніх досліджень і публікацій. Окремі елементи нормотворчої, експертної, спостережної діяльності в правовому статусі суб'єктів контролю розглядаються в загальній теорії адміністративного, конституційного права, предмета правосуддя до судоустрою (це праці таких учених, як В.Б. Авер'янов, О.Ф. Андрійко, С.В. Бардаш, Ю.П. Битяк, В.В. Галунько, В.М. Гаращук, І.П. Голосніченко, А.М. Колодій, Т.О. Коломоєць, В.К. Колпаков, О.В. Кузьменко, В.Я. Малиновський, О.М. Музичук, О.В. Шевчук та інші). Водночас ученим, як правило, аналізується або специфіка діяльності певного органу (наприклад, Президента України чи Вищої ради правосуддя), або ж певна адміністративна діяльність як загальноправове явище (наприклад, правотворчість). Тоді як поєднання нормотворчої, експертної, спостережної діяльності з предметом контролю за суддями у фахових дослідженнях практично не представлено.

Постановка завдання. Метою статті є вивчення, характеристика та систематизація нормотворчості, експертизи та моніторингу як адміністративних форм контролю за суддями та процедур їх здійснення.

Результати дослідження. Прийняття нових, зміна чи скасування чинних законів $\epsilon$ прерогативою єдиного законодавчого органу України - Парламенту, який виконує цю функцію на пленарних засіданнях. Враховуючи той факт, що для набуття чинності законом потрібне його підписання Президентом (з правом останнього ветувати закон і повернути до Верховної Ради зі своїми зауваженнями), в цій процедурі також бере участь і Глава Держави.

Локальна правотворчість органів суддівського врядування та суддівського самоврядування - можливість зазначених суб'єктів приймати нормативні акти, що є обов'язковими для суддів чи цих органів. Це можуть бути рішення з різних загальноуправлінських чи організаційних питань судової системи (наприклад, рішення Вищої ради правосуддя про затвердження зразка дисциплінарної скарги (скарги щодо дисциплінарного проступку судді або суддів); рішення Вищої кваліфікаційної комісії суддів про затвердження власного регламенту; рішення Ради суддів із питань забезпечення суддівської незалежності, рішення зборів суддів конкретного суду про обрання слідчих суддів і так далі. Натомість правотворчість Конституційного Суду полягає у формуванні правових позицій у процесі вирішення справ за конституційними зверненнями, які фактично $\epsilon$ новими правовими нормами, що хоча і не мають прямої дії, проте активно впливають на процес правозастосування, використовуються під час вирішення спірних ситуацій.

Експертне оцінювання регулюючого законодавства як спеціального об'єкта дослідження здійснюється Конституційним Судом України, який формалізує рішення про конституційність законів України (їх відповідність основному закону). Рішення органу конституційної юрисдикції є остаточним і не може бути оскарженим. Встановлений факт неконституційності правової норми зумовлює втрату ними чинності з дня ухвалення відповідного рішення судом або пізнішої дати, зазначеної в рішенні. Експертне дослідження державними та недержавними суб'єктами стосується, як правило, проєктів законів і полягає в оцінці потенційного позитивного ефекту від ïх прийняття на судову сферу. Серед таких суб'єктів із міжнародним статусом насамперед варто згадати Венеціанську комісію (Європейську комісію за демократію через право), а також провідні наукові установи - Національний юридичний університет імені Ярослава Мудрого, Інститут держави і права імені В.М. Корецького НАН України, Одеську юридичну академію тощо. Висновки цих суб' єктів мають факультативний характер, водночас володіють репутаційним потенціалом (зокрема, це стосується висновків Венеціанської комісії).

Експертне оцінювання регулюючого законодавства в межах розгляду судових справ проти держави України в Європейському суді з прав людини $є$ побічною процедурою оцінки відповідності національного законодавства європейським принципам функціонування суду під час розгляду заяви конкретного скаржника проти України. За результатами такої оцінки, окрім сформованої правової позиції (тобто лексичного позначення відповідності чи невідповідності певного правового припису європейським засадам функціонування суду), може також прийматися рішення (формуватися подання) до Кабінету Міністрів України про вжиття заходів загального характеру - забезпечення усунення недоліків системного характеру шляхом внесення змін до чинного законодавства та практики його застосування.

Спостереження за дотриманням закону суддями у професійній діяльності, за дотриманням суддями та кандидатами на посаду судді кваліфікаційних та особистісних вимог до особи судді означає постійний процес моніторингу дотримання суддями вимог матеріального та процесуального права під час вирішення судових справ; суддями (кандидатами на їхні посади) - законодавчих вимог до особи судді, зокрема, в частині доброчесності, законності походження майна, відповідності видатків рівню доходів і так далі. При цьому можна стверджувати про тенденцію 
своєрідної «спеціалізації» щодо певних форматів такого моніторингу різними суб'єктами. Як правило, учасники судових процесів, фахівці у сфері права, науковці аналізують законність професійної діяльності судді; тоді як громадські активісти, громадські організації моніторять відповідність кваліфікаційним, особистісним критеріям для посади судді.

Моніторинг оптимальності структури судоустрою, правового статусу судів, суддів, органів суддівського врядування та самоврядування від вищезгаданої процедури різниться предметом та об'єктом контролю. Тобто спостерігаються діяльність, статус, зв'язки суддів, а також загальний стан судової системи, дієвість правосуддя, незалежність суду, порядок формування суддівського корпусу, порядок формування та функціонування органів суддівського врядування та самоврядування.

Моніторинг додержання вимог законодавства щодо врегулювання конфлікту інтересів характеризує обов'язок судді (членів Вищої кваліфікаційної комісії суддів) подавати Раді суддів інформацію про наявність реального чи потенційного конфлікту інтересів та обов'язок останнього органу забезпечити його врегулювання. Тобто в цьому випадку суб'єкт контролю чітко визначений, не може делегувати власних повноважень третій особі.

Організаційно-фінансове забезпечення роботи суду є сукупністю заходів аналізу щодо поточних і майбутніх потреб суду на фінансування оплати праці суддів, створенням належних умов праці (приміщення, канцтовари, офісна та комп’ютерна техніка), розподіл обов'язків між суддями, визначення робочого навантаження на суддю, вирішення інших матеріальних, побутових, господарських, організаційних питань, які виникають у суду як роботодавця щодо судді.

Аналітика дисциплінарної та кваліфікаційної практики органів суддівського врядування $\epsilon$ консолідованою, систематизованою, обробленою за вільними критеріями інформацією щодо практики Вищої ради правосуддя (іiі дисциплінарних палат) по розгляду справ стосовно несумісності, дисциплінарного провадження (зокрема, кількості звільнених суддів за дисциплінарні правопорушення), кваліфікаційного оцінювання Вищої кваліфікаційної комісії суддів. Причому така аналітика може готуватися, оприлюднюватися як самими органами суддівського врядування, так і фізичними чи юридичними особами з використанням у своїх дослідженнях відкритої інформації з цієї проблематики.

Висновки. Нормотворчість - форма контролю, що забезпечує вчасне, професійне, ефективне формування та коригування чинного законодавства в царині судоустрою та правосуддя в цілях зростання його ефективності та відповідності демократичним, правовим засадам функціонування суду. Щодо цієї форми присутні такі адміністративні процедури: 1) прийняття нових, зміна чи скасування чинних законів; 2) локальна правотворчість органів суддівського врядування та суддівського самоврядування, Конституційного Суду України.

Експертиза як форма контролю за судом та суддями - це виконання правової оцінки, юридичної експертизи національного законодавства, яке стосується сфери судоустрою та правосуддя, за результатами якої приймається юридично значиме рішення, яке має обов'язковий чи факультативний характер, може зумовити втрату чинності правових норм чи зобов'язання держави відкоригувати їхній зміст. Присутні такі адміністративні процедури в межах цієї форми контролю: 1) експертне оцінювання регулюючого законодавства (проєктів) як спеціального об'єкта дослідження; 2) експертне оцінювання регулюючого законодавства в межах розгляду судових справ проти держави України в Європейському суді з прав людини.

Спостереження як форма контролю - систематична моніторингово-аналітична функція визначеного або невизначеного законом кола осіб щодо суду та суддів, що полягає в накопиченні, оприлюдненні, передачі третім особам зібраних даних, які стосуються оптимальності структурних зв'язків у судовій системі, систематичне спостереження за дотриманням закону суддями, вивчення дисциплінарної практики Вищої ради правосуддя тощо з обмеженою можливістю настання прямих юридичних наслідків для об'єктів контролю.

Виокремлюємо такі види адміністративних процедур, що відповідають моніторингу (спостереженню, аналізу) як формі контролю: 1) спостереження за дотриманням закону суддями у професійній діяльності; 2) спостереження за дотриманням суддями та кандидатами на посаду судді кваліфікаційних та особистісних вимог до особи судді; 3) моніторинг оптимальності структури судоустрою, правового статусу судів, суддів, органів суддівського врядування та самоврядування; 4) моніторинг додержання вимог законодавства щодо врегулювання конфлікту інтересів; організаційно-фінансове забезпечення роботи суду; 5) аналітика дисциплінарної та кваліфікаційної практики органів суддівського врядування.

Виділені нами форми контролю - нормотворчість; експертиза; моніторинг (спостереження, аналіз) та адміністративні процедури, що здійснюються в їхніх межах, у найбільш повному 
та оптимальному форматі характеризують формалізацію управлінського впливу на судову сферу. Водночас ці форми (процедури) значною мірою $є$ орієнтирами для вивчення правового регулювання, правозастосування у сфері контролю за суддями (судом), адже різні елементи механізму нагляду іноді можуть бути одночасно віднесені до різних форм (процедур). До того ж зазначені форми та процедури не є сталими поняттями (явища) - динамізм розвитку суспільства, державотворення, перманентні законодавчі новації можуть зумовлювати їх оновлення та зміни, а так само об'єднання чи поділ наявних форм, переміщення адміністративних процедур з однієї форми до іншої.

\section{Список використаних джерел:}

1. Шпак Ю.А. Методологічні підходи до визначення поняття нормотворчості органів місцевого самоврядування. Науковий вісник Львівського держсавного університету внутрішніх справ. Серія : Юридична. 2013. № 1. C. 145-152. URL: http://nbuv.gov.ua/UJRN/Nvlduvs_2013_1_18.

2. Гончаренко В.Г. Організаційні та правові проблеми судової експертизй в Україні. Часопис Академії адвокатури України. 2011. № 1 (10). C. 1-5. URL: http://virtuni.education.zp.ua/info cpu/sites/ default/files $/ \% 20 \% \mathrm{D} 1 \% 81 \% \mathrm{D} 1 \% 83 \% \mathrm{D} 0 \% \mathrm{~B} 4 \% \mathrm{D} 0 \% \mathrm{BE} \% \mathrm{D} 0 \% \mathrm{~B} 2 \% \mathrm{D} 0 \% \mathrm{BE} \% \mathrm{D} 1 \% 97 \% 20 \% \mathrm{D} 0 \% \mathrm{~B} 5 \% \mathrm{D}$ 0\%BA\%D1\%81\%D0\%BF\%D0\%B5\%D1\%80\%D1\%82\%D0\%B8\%D0\%B7\%D0\%B0.pdf.

3. Копча В.В. Тактика використання спеціальних знань у кримінальному судочинстві. Призначення і проведення судових експертиз. Науковий вісник Ужгородського національного університету. 2017. Вип. 47. Т. 3. С. 107-114. URL: http://www.visnyk-juris.uzhnu.uz.ua/file/No.47/part_3/24.pdf.

4. Кодекс адміністративного судочинства України : Кодекс, Закон України від $\overline{6}$ липня 2005 p. № 2747-IV. URL: https://zakon.rada.gov.ua/laws/show/2747-15.

5. Виконавча влада і адміністративне право / за заг. ред. В.Б. Авер'янова. Київ, 2002. 668 с.;

6. Бариніна-Закірова М.В. Нотатки про методи урядового фінансового контролю. Фінансовий контроль. 2005. № 1. С. 53-60.

ОКСЮТА О.Г.

\section{ПРАВОВІ ЗАСАДИ ОРГАНІЗАЦІЇ АДМІНІСТРАТИВНОГО СУДОЧИНСТВА ТА МІСЦЕ СЕРЕД НИХ АДМІНІСТРАТИВНО-ПРАВОВОГО РЕГУЛЮВАННЯ}

Мета статті - розглянути правові засади організації адміністративного судочинства та визначити, яке місце серед них належить адміністративно-правовому регулюванню. У статті на основі аналізу наукових поглядів вчених та норм чинного законодавства України надано характеристику правовим засадам організації адміністративного судочинства. Обгрунтовано, що адміністративно-правове регулювання займає домінуюче положення у системі правових засад організації адміністративного судочинства, адже саме норми цієї галузі права містять у собі основні положення відносно учасників таких правовідносин, їхньої компетенції, механізму взаємодії та сфери впливу. Визначено, що положення Закон України «Про державну службу» визначаються принципи, правові та організаційні засади забезпечення публічної, професійної, політично неупередженої, ефективної, орієнтованої на громадян державної служби, яка функціонує в інтересах держави і суспільства, а також порядок реалізації громадянами України права рівного доступу до державної служби, що базується на їхніх особистих якостях та досягненнях. Доведено, що на законодавчому рівні правові засади організації адміністративного судочинства

(C) ЄРМАКОВА Г.С. - кандидат філософських наук, доцент кафедри історії та теорії держави і права (Міжрегіональна Академія управління персоналом) 